\title{
Factors Affecting The Growth Of Regional Revenue In The District/City Of North Sumatera
}

\author{
Idhar Yahya1', M. Zainul Bahri Torong2, Muslich Lufti ${ }^{3}$ \\ Department of Accounting \\ University of Sumatera Utara, Medan, Indonesia \\ idhar@usu.ac.id ${ }^{1}$, zainul.bahri@usu.ac.id ${ }^{2}$, muslich.lufti@usu.ac.id ${ }^{3}$
}

\begin{abstract}
This study aims to examine and analyze the effect of capital expenditures, the general allocation fund, revenue-sharing, and region own transfer fund towards the growth of the local source revenue with population as moderating variable. This is a causal study. The population used in this study is all of the regencies / cities in North Sumatra, which is 33 in total. The data used is secondary data. Multiple linear regression is used to test and analyze the effect of capital expenditures, the general allocation fund, revenuesharing, and transfer fund toward the growth of region own source revenue. Residual test is used to test and analyze the number of inhabitants as moderating variable. The results showed that capital expenditure, general allocation fund, revenue-sharing, region own transfer fund simultaneously and partially have positive and significant effects on the growth of local source revenues. Partially, only general allocation fund and region own transfer funds have positive and significant effect, whereas capital expenditure and revenue sharing don't have positive and significant effect. The number of inhabitants as a moderating variable can moderate the relationship between capital expenditures, general allocation fund, revenue sharing, and region own transfer fund.
\end{abstract}

Keywords-capital expenditure; general allocation fund; revenue sharing, region own transfer fund; the number of residents; local revenues

\section{INTRODUCTION}

The management of regional government in Indonesia enters new eras as regional autonomy and fiscal decentralization are validated, i.e the validation of Law 32/2004 and Law 33/2004 (Law no.32 and 33, 2004). It is expected that improvement in services will happen in many sectors. Service improvement will motivate investors to start business in these regions. This expectation will become reality if there is a serious effort from government by giving various investation facilities support. This investation increase is forth expected to increase Region/District Own Source Revenue, therefore the reliance on transfer funds from central government. However, in reality, up until now, transfer funds from central government still acts as the mainstay for Regional Government Budget (RGB). The data shows that the most districts in Indonesia have 15\% lower Region/District Owns Source Revenue than the total region source revenue, in some districts/cities the number is even lower this and this phenomenon also happens in North Sumatera.
Central government has given four important elements to region/district government in regional autonomy. According to Rondinelli, they are political decentralization, administration, fiscal, and economy where all four of the elements are related (Litvack et. al,1999). If all the elements are combined into a firm concept of grand design and governed effectively and efficiently, region ability and dependency will be formed in performing its function as regional autonomy. An important indicator of regional financial authority is the amount of Region/District Own Source. Region Own Source Revenue (ROSR) gives the picture of dependency and ability of region in autonomy. The demand of increasing Region Own Source Revenue becomes bigger as there is an increase in government authority given to the regions along with the diversion of personnel, tools, funding, and documentation to regions/districts in large number.

The ability of financial in one region/district has significant effect toward the overall performance of regional government. If the regional financial ability is low, this will negatively affect the 
public services that will ultimately induce intervention of central government, or even in the extreme form, some function of regional government will be diverted to other institution. Hence, regional government is in charge of increasing financial capability by incorporating various concrete initiatives, which will make many alternatives in development strategies that will be poured in regional policy.

The main sources of regional internal fund are building tax, lisency, retribution (Ernest, 2014). Another problem regarding this fund is collecting source revenue, uncomplete data, and lack of motivation to increase revenue, aside of the lack of people in tax collector department. Study was related to the effect of regional government internal revenue and infrastructure. The better internal revenue, the better infrastructure is (Adenugba, 2013).

The increase in tax received functions as law enforcement and tax administrators are fully responsible of it. In this country, there is also a problem in labour capablities and tax collecting system (James et.al, 2012). The current problem of regional government was increasing region own source revenue from various sectors, i.e local tax and licensing (Bartle, 2003). Meanwhile, all significant tax in Indonesia, including value added tax, private income tax, and institution income tax, remain under the control of central government. The consequence is vertical fiscal disparity between regional government expenditure and its revenue is very big and this happens in all regional governments in Indonesia (Neckard et.al, 2006).

According to Law.33/2004 regional government receives transfer funds from central government, i.e General Allocation Fund (GAF), Specific Allocation Fund (SAF), and Revenue Sharing Fund (RSF), which comprises of tax revenue transfer funds and natural resources transfer funds. For District Government especially, sharing fund also comes from Regional Government. With the large amount of fund transferred, it is expected that regional government budget will increase, which in turn will increase District Own Source Revenue (DOSR). However, in reality, up until now, District Own Source Revenue has not shown a significant increase, otherwise regional government spending plan is not equal to regional financial capabilities. There is a strong correlation between government transfer funds and regional expenditure (Holzt et.al,1994). Furthermore, Legrenzi and Milas find empirical proves that in the long term, the transfer funds affect the investment expenditure and reducing the amount of transferred funds can decrease regional expenditure (Abdullah et.al,2003).

For regional government, GAF and RSF existence are still dominant, thus, if both types of funding are cut completely, regional government will be paralized and cannot do its activity. In shared Region Own Source Revenue has no meaning if not supported by GAF and RSF.

\section{REFERENCES STUDY}

ROSR is a region revenue received based on regional rules of constitution. ROSR is a revenue received from regional resources which is managed by regional government and is a backbone in regional financing, therefore the ability to perform regional economy function can be measured from how big or small the contribution of ROSR toward Regional Government Budget (RGB). The bigger the contribution given by ROSR to RGB, the less dependent that region is on the central government. In reality, ROSR contribution is still so small toward RGB.

\section{A. Investment Expenditure}

Investment expanditure is an expenditure done to buy or make tangible assets which are profitable for more than 12 months that can be used in government activity, for example in the form of estate, tools and machines, buildings, street, irrigations and networks, and other tangible (Minister Regulation, 2006). Investment expenditure by regional government is also a regional investment in order to give public services.

\section{B. General Allocation Funds (GAF)}

GAF in many countries are called General Purpose Grants is a type of transfer funds that becomes the general income for its receivers. This type of sharing is also called unconditional grants, where grants given are not related to any requirement from the giver. The user of unconditional grants is free to support fiscal decentralization which gives freedom for receivers to allocate the sharing according to local priorities. GAF is a fund stems from NGB, which is allocated in order to even the financial capability between 
regions to fund the expenditure to do decentralization.

\section{Revenue Sharing Funds (RSF)}

RSF are classed into two groups, RSF from the tax and RSF from natural resources. RSF is a government source revenue which is shared with districts/regions where the location of the revenue produced is proportional to the funds collected (proportionality of collection). Revenue sharing funds is given to alleviate vertical discrepancies between central and regional government. Vertical discrepancies are caused by the authority of source revenue by the central government that of regional government, therefore locals cannot fund their activities without funds shared by central government. Vertical discrepancies can also be interpretted as discrepancies between regional source revenue potential and the need to fund regional matters. RSF is generaly unconditional.

\section{Transfer fund from Province Government}

This source of fund is also important for District/City Government. As this source of funds is pretty significant for that district. Regional government is authorized to collect local tax and retribution in accordance with its autonomy activity. Local tax and retribution is collected by province government and district/city government. Some of the tax and retribution collected by province government will be returned to district/city government.

\section{E. Population}

The population of Indonesia is all people who domiciled in geographical territory of Indonesia for six months, but wants to settle Indonesia. The changes of population that domiciled in North Sumatera is caused by three main reasons, i.e. fertility, mortality, and migration. Census result of population in 2010 is that North Sumatera Province is domiciled by 12.982 .204 people, with population density approximately 188 people per $\mathrm{km}^{2}$.

\section{STUDY METHOD}

This study is casual associative type of study using quantitative data type. Population and sample used in the study is 33 District/Cities in North
Sumatera Province. The data used is pooling data, that is the combination of District/City, and time series, i.e. realization report of RGB, and there are 29 samples that meet the criteria with time span of 4 years. The data is obtained from the related institutions, such as North Sumatera Central Bureau of Statistics (CBS) and Direktorat Jenderal Perimbangan Keuangan Pusat dan Daerah (DJPKN). Another supporting data is obtained by visiting several districts/cities as a means to cross check on several important data.

\section{A. Analysis Technique}

One of the requirement in conducting hypothesis test is by using classic assumption test, i.e. normality test, multicollinearity test, autocorrelation test, and heteroscedasticity test. Before that, analytical statistic descriptive is performed.

\section{B. Hypothesis Test}

Hypothesis test used in the study is multiple regression model and residual analysis regression model. This model is used to know partially and simultaneously.

\section{1) First Hypothesis Test}

- Regression Linear

Multiple regression linear is performed to test the independency of variables on dependent variables of studied variables. The formula of the regression is,

$$
\mathrm{Y}=\alpha+\beta 1 \mathrm{X} 1+\beta 2 \mathrm{X} 2+\beta 3 \mathrm{X} 3+\beta 4 \mathrm{X} 4+\varepsilon
$$

This regression analysis result is tested using $\mathrm{F}$ test in order to know the effect simultaneously and t-test to know the effect partially.

\section{- $\quad$ F-Test and T-Test}

Statistic F-test is used to test how much independent variables simultaneously affect dependent variables. Meanwhile, statistic t-test is used to test how much independent variables partially affect dependent variables or to see what variables have more effect among the variables.

\section{2) Second Hypothesis Test}

\section{- Interaction Test and Residual Test}

In the second hypothesis test, residual test is used to test how much moderating variable 
moderate the direct effect of independent variables on dependent variables or to see wether the existence of moderating variable strengthens or weakens the effect among the variables.

The residual test formula is :

$$
\begin{gathered}
\mathrm{X} 5=\alpha+\beta 1 \mathrm{X} 1+\beta 2 \mathrm{X} 2+\beta 3 \mathrm{X} 3+\beta 4 \mathrm{X} 4+\varepsilon \ldots . .1 \\
\mathrm{E}=\alpha+\beta 1 \mathrm{Y}
\end{gathered}
$$

Decision making criteria is if F-calculated $>\mathrm{F}$ table with significant level of $5 \%$, then $\mathrm{H}_{2.0}$ is rejected or hypothesis accepted. Nevertheless, if Fcalculated $<$ F-table with significant level of $5 \%$ then $\mathrm{H}_{2.0}$ is accepted or hypothesis rejected.

\section{RESULT AND DISCUSSION}

The number of samples $(\mathrm{N})$ is 116 . Investment Expenditure (IE) is received from District/City in North Sumatera by searching for the highest and the lowest, and also the average and the highest standard deviation for IE, GAF, RSF, Fund Tax Bourne by the Government, Number of Population, and LR. Based on normality test, therefore the value of Kolmogrov-Smirnov can be concluded that the data is distributed normally. Multicollinearity does not happen among the independent variables of the study. Autocorrelation also does not happen.

\section{- $\quad$ First Hypothesis Test}

From ANOVA (Analysis of Variance) test result, it shows that investment expenditure, General Allocation Fund, Revenue Sharing Funds, and Province Transfer Funds affect local revenues greatly. The result of the test partially shows that General Allocation Funds (GAF) affect Local Revenue considerably, while Investment Expenditure Variable (IE), RSF, and Number of Population (NP) Variable do not affect the growth of Local Revenue (LR).

\section{- $\quad$ Second Hypothesis Test (Moderating)}

The residual equation between dependent variables on absolute residual value of moderating variable is Number of Population produces such residual test equation model as:

$$
\begin{aligned}
& \mathrm{X} 5=-21.539+0.032 \mathrm{X} 1+0.778 \mathrm{X} 2+0.109 \mathrm{X} 3+ \\
& 0.426 \mathrm{X} 4+\varepsilon \\
& \mathrm{e}=1.523-0.053 \mathrm{Y}
\end{aligned}
$$

Based on Number of Population test, the coefficient parameters are of negative value. A variable is said moderating if it has negative coefficient parameters and has substantial effect. The conclusion from this residual test with t-test and f-test is Investment Expenditure, General Allocation Funds, Revenue Sharing Funds, Province Transfer Funds have positive and significant effect on the growth of Local Revenues in districts/cities in North Sumatera Province. Population acts as moderating variable, which strengthens the relation between Investment Expenditure, General Allocation Funds, Revenue Sharing Funds, Province Transfer Funds on Local Revenues.

\section{CONCLUSIONS}

Investment Expenditure, General Allocation Funds, Revenue Sharing Funds, Province Transfer Funds, and Number of Population simultaneously affect Local Revenues greatly in District/City Government in North Sumatera. Partially, only General Allocation Funds Variable has significant effect on Local Revenues in District/City Government in North Sumatera, meanwhile Investment Expenditure, Revenue Sharing Funds, Province Transfer Funds, Number of Population do not have significant effect on Local Revenues. Number of Population acts a moderating variable, which strengthens the relation between Investment Expenditure, General Allocation Funds, Province Transfer Funds on Local Revenues in District/City Government in North Sumatera.

District/City Government in North Sumatera can develop the potential of local revenue sources, in order to build the economy in that place, so that it can increase Local Revenues or Local Income. Using this approach, it is expected that regional independency can increase.

\section{REFERENCES}

Abdullah, Sukriy and A.Halim. (2003). Pengaruh Dana Alokasi Umum (DAU) dan Pendapatan Asli Daerah (PAD) terhadap Belanja Pemerintah Daerah Studi Kasus 
Kabupaten/Kota di Jawa dan Bali, Simposium Nasional Akuntansi VI, Jogjakarta, 1140 1159.

Adenugba, Ogechi, (2013). Journal of Educational and Social Research, Vol. 3 (2) May 2013, ISSN 2239-978X.

Bartle J. R. (2003). Trends in Local Government Taxation in the 21st Century. Spectrum: Journal of State Government, 76 (1): 26-29.

Ernest Adu-Gyamfi, Public Policy and Administration Review March. (2014). Vol. 2, No. 1, pp. 97122, Published by American Research Institute for Policy Development.

Holtz, Eakin, Doglas, Harvey S, \& Schuyley Tilly (1994). Intertempora Analysis of State An Local Government Spending; Theory and Test. Journal of Urban Economics 35;159-174.

James Abiola, M. Asiweh. (2012). International Journal of Business and Social Science, Vol. 3 No. 8.

Law No. 32 on Local Government. (2004).

Law No. 33. Finance Balance between Central and Local Government. (2004).

Litvack, Jennie, Seddon, Jessica. (1999). Desentralization Brefing Notes, The Word Bank, Washington D.C.

Minister Regulation No. 13 on Local Management Finance Manual. (2006).

Neckard, Sebastian and A.Shah. (2006). Local Governance in Developing Countries, The World Bank. 